\title{
Resistance of Oryza sativa and Oryza glaberrima Genotypes to RBe24 Isolate of Rice Yellow Mottle Virus in Benin and Effects of Silicon on Host Response
}

\author{
Vital Kouessi Sixte Anato ${ }^{1}$, Yves Agnoun ${ }^{2 *}$, Joèl Houndjo ${ }^{1}$, Aderonke Oludare ${ }^{3}$, Clement Agbangla ${ }^{4}$, \\ Malachy Akoroda ${ }^{1,5}$ and Victor O. Adetimirin ${ }^{1,5}$ \\ ${ }^{I}$ Pan African University Institute of Life and Earth Sciences (PAULESI), University of Ibadan, Ibadan 200284, Nigeria \\ ${ }^{2}$ Université Nationale d'Agriculture (UNA), 01 B.P. 55, Porto-Novo, Benin \\ ${ }^{3}$ AfricaRice, 01 B.P. 2031, Cotonou, Benin \\ ${ }^{4}$ University of Abomey Calavi (UAC), 01 BP: 526, Cotonou, Benin \\ ${ }^{5}$ Department of Crop and Horticultural Sciences, University of Ibadan, Ibadan 200284, Nigeria
}

(Received on November 6, 2020; Revised on July 15, 2021; Accepted on July 15, 2021)

Rice yellow mottle virus (RYMV) is the most harmful virus that affects irrigated and lowland rice in Africa. The RBe24 isolate of the virus is the most pathogenic strain in Benin. A total of 79 genotypes including susceptible IR64 (Oryza sativa) and the resistant TOG5681 (O. glaberrima) as checks were screened for their reactions to RBe24 isolate of RYMV and the effects of silicon on the response of host plants to the virus investigated. The experiment was a three-factor factorial consisting of genotypes, inoculation level (inoculated vs. non-inoculated), and silicon dose $(0,5$, and $10 \mathrm{~g} / \mathrm{plant})$ applied as $\mathrm{CaSiO}_{3}$ with two replications and carried out twice in the screen house. Significant differences were observed among the rice genotypes. Fifteen highly resistant and eight resistant genotypes were identified, and these were mainly $O$. glaberrima. Silicon application did not affect disease incidence and severity at 21 and 42 days after inoculation (DAI); it, however, significantly increased plant height of inoculated $(3.6 \%$ for $5 \mathrm{~g} \mathrm{CaSiO}_{3} /$ plant and $6.3 \%$ for $10 \mathrm{~g} \mathrm{CaSiO}_{3}$ /plant) and non-inoculated $\left(1.9 \%\right.$ for $5 \mathrm{~g} \mathrm{CaSiO}_{3} /$ plant and $4.9 \%$ for $10 \mathrm{~g} \mathrm{CaSiO}_{3} /$ plant) plants at $42 \mathrm{DAI}$, with a reduc-

*Corresponding author.

Phone) +22997089577

E-mail)yagnoun@yahoo.fr

Handling Editor : Inhwa Yeam

(c) This is an Open Access article distributed under the terms of the Creative Commons Attribution Non-Commercial License (http:// creativecommons.org/licenses/by-nc/4.0) which permits unrestricted noncommercial use, distribution, and reproduction in any medium, provided the original work is properly cited.

Articles can be freely viewed online at www.ppjonline.org. tion in the number of tillers $(12.3 \%$ for both 5 and $10 \mathrm{~g}$ $\mathrm{CaSiO}_{3} /$ plant $)$ and leaves $\left(26.8 \%\right.$ for $5 \mathrm{~g} \mathrm{CaSiO}_{3} /$ plant and $28 \%$ for $10 \mathrm{~g} \mathrm{CaSiO}_{3} /$ plant) under both inoculation treatments. Our results confirm $O$. glaberrima germplasm as an important source of resistance to RYMV, and critical in developing a comprehensive strategy for the control of RYMV in West Africa.

Keywords : Benin, Oryza glaberrima, rice, RYMV, silicon

Rice (Oryza sp.) is one of the most important food crops in the world. Africa accounts for $4 \%$ of world production. Average rice yield of $2.6 \mathrm{t} / \mathrm{ha}$ in Africa falls considerably short of the average world yield of $4.6 \mathrm{t} / \mathrm{ha}$ (Food and Agriculture Organization of the United Nations, 2019), although, rice production, which was 21 million tonnes in 2007, increased to 31.1 in 2017 (Food and Agriculture Organization of the United Nations, 2019). Notwithstanding this increase, many countries in the continent continue to rely heavily on rice imports as local production has not been able to meet up the growing consumption needs (Food and Agriculture Organization of the United Nations, 2017a).

As a source of calories, rice ranks third for most of the countries in West Africa (Fiamohe et al., 2018; Food and Agriculture Organization of the United Nations, 2017b). In Benin Republic, despite several efforts made to increase local production, yields of irrigated rice rarely exceeded $2.07 \mathrm{t} / \mathrm{ha}$ (Diagne et al., 2013). This is largely due to biotic stresses, among which are viruses. Rice yellow mottle virus (RYMV), a Sobemovirus (Hull, 1988), is one of the 
most destructive viruses affecting rice cultivation in both irrigated and lowland ecologies in Africa (Abo et al., 1997; Kouassi et al., 2005, Séré et al., 2013). Yield losses due to RYMV in smallholder farms range from $10 \%$ to $100 \%$, depending on the time of infection, level of susceptibility of rice varieties cultivated and the prevailing climatic conditions (Issaka et al., 2012; Kam et al., 2013; Kouassi et al., 2005; Laha et al., 2017; Séré et al., 2013). The virus was first reported in Kenya (Bakker, 1970). Extensive characterization of the viral strains revealed different genetic groups with gradual differentiation from East to West Africa (Pinel-Galzi et al., 2015). Due to its complex epidemiology, varietal resistance has been the major management method used to control the disease (Traoré et al., 2009).

Among accessions of the two cultivated rice species, $O$. sativa (originating from Asia and cultivated worldwide) and $O$. glaberrima (endemic to Africa and locally cultivated in West Africa), several resistant accessions were found mostly among the African rice species (Thiémélé et al., 2010). Researches in molecular rice breeding have led to the identification of three major resistance genes named RYMV1, RYMV2, and RYMV3 in O. sativa and $O$. glaberrima, the two cultivated species. The first resistance gene (RYMV1) encodes the eukaryotic translation initiation factor eIF(iso)4G (Albar et al., 2006) with five allelic variants. These include one susceptible allele rymv11 carried by IR64, and four resistance alleles viz. rymv12 , rymv1-3, rymv1-4, and rymv1-5, carried by Gigante $(O$. sativa), tropical Oryza glaberrima (TOG) 5681, TOG5672, and TOG5674, respectively (Albar et al., 2006; Thiémélé et al., 2010). The second resistance gene (RYMV2) is governed by a recessive allele and codes for CPR5-1, a probable component of the nuclear pore complex involved in the regulation of defense mechanisms (Pidon et al., 2017). The third gene (RYMV3), with NB-LRR as a very convincing candidate gene, is probably involved in the virus recognition mechanism (Pidon et al., 2017).

Attempts at the introgression of resistance alleles from O. glaberrima sources into high yielding but susceptible $O$. sativa varieties by conventional breeding have met with limited success because of genetic barriers (Heuer et al., 2003; Jones et al., 1997). Although, the interspecific lowland rice varieties, the NERICAs (New Rice for Africa), were obtained using TOG5681 (O. glaberrima) and IR64 (O. sativa) as parents (Sié et al., 2005), these varieties did not exhibit the high resistance to RYMV of their O. glaberrima parent (Agnoun, 2013; Ndjiondjop et al., 2008). In addition, breakdown of the resistance in some rice genotypes carrying rymv1-2 and rymv1-3 alleles has been observed in experimental stations (Pidon et al., 2017).
This raises concerns on the durability of the known RYMV resistance genes (Hébrard et al., 2018; Kobayashi et al., 2014). These observations suggest that available rice varieties may be vulnerable to RYMV in areas where a great diversity of the virus exists, such as in Benin Republic (Oludare et al., 2016).

The use of varietal resistance combined with appropriate agronomic management, one of which is the use of silicon (Si), may offer a very practical and cost-effective solution to overcome RYMV. Silicon is known to play a beneficial role in achieving healthy growth and development in many plant species and also improves tolerance to abiotic stresses such as salinity, drought, chilling, freezing, iron toxicity etc. (Epstein, 1994, 1999; Liang, 1999; Liang et al., 2005, 2007; Ma et al., 2001; Mbonankira, 2014). It is also known to improve mineral nutrient uptake and alleviate metal toxicity in plant species (Frantz et al., 2011; Liang et al., 2007; Mbonankira, 2014). The beneficial role of silicon in improving resistance to biotic stresses has also been reported (Tsujimoto et al., 2014). Many members of the family Poaceae, especially rice, are known to accumulate silicon (Tamai and Ma, 2003), which is abundant in the soil (Janislampi, 2012). Plants can accumulate silicon at concentrations higher than those of many essential macronutrients, often in excess of $1,000 \mathrm{mg} / \mathrm{kg}$ (Epstein, 1999; Tsujimoto et al., 2014). It is, however, not required by most plant species for the completion of their life cycle (Marschner, 1995). Silicon taken up by the rice plant is usually deposited in various organs such as husks, leaves, leaf sheath, culm and roots (Zhu et al., 2004). Its presence in cell wall fiber makes the cell wall tough, reduces plant transpiration and improves photosynthesis rate due to its association with leaf ultrastructure, chlorophyll content and ribulose bisphosphate carboxilase activity (Epstein, 1994). In effect, silicon deposition in leaves improves resistance/ tolerance to pests and diseases (Meyer and Keeping, 2001) and remediates nutrient imbalances (Epstein, 1994; Ma et al., 2001; Savant et al., 1996). Silicon has been reported to increase rice yield under multiple stress conditions of lowland ecosystems (Meharg and Meharg, 2015).

The first study on silicon nutrient in relation to viral disease control was reported by Zellner et al. (2011). These authors observed that silicon-fertilized plants of tobacco (Nicotiana tabacum) inoculated with tobacco ringspot virus (TRSV) exhibited higher foliar Si-content with lower TRSV systemic symptom formation. No previous study to date has reported the effects of silicon on the control of viral disease on important food security crops. The objectives of this study were to evaluate the reaction of diverse rice genotypes to the RBe 24 isolate of RYMV and determine 
Table 1. List of the 79 genotypes screened for disease resistance with RBe24 isolate of rice yellow mottle virus under silicon fertilizer

\begin{tabular}{|c|c|c|c|c|c|c|c|c|c|}
\hline No. & Code & Genotypes & Species & Source & No. & Code & Genotypes & Species & Source \\
\hline 1 & VB1 & $\begin{array}{l}\text { WAB 2066-6-FKR4-WAC1- } \\
\text { TGR1-B-WAT-B16 }\end{array}$ & Interspecific $^{\mathrm{a}}$ & INERA & 41 & V23 & PL55-2 & O. glaberrima & AfricaRice \\
\hline 2 & VB2 & WAB 2066-WAT21-1-B-1-3 & Interspecific & INERA & 42 & V24 & PL55-7 & O. glaberrima & AfricaRice \\
\hline 3 & VB5 & WAB 2152-TGR2-WAT1-2 & Interspecific & INERA & 43 & V25 & PL57-4 & O. glaberrima & AfricaRice \\
\hline 4 & VB9 & $\begin{array}{l}\text { WAB 2066-6-FKR4-WAC1- } \\
\text { TGR1-B-WAT-B11 }\end{array}$ & Interspecific & INERA & 44 & V26 & PL57-5 & O. glaberrima & AfricaRice \\
\hline 5 & VB10 & SAHEL 177 & Interspecific & INERA & 45 & V27 & S2-6 & O. glaberrima & AfricaRice \\
\hline 6 & VB11 & SAHEL 328 & Interspecific & INERA & 46 & V29 & PL58-1 & O. glaberrima & AfricaRice \\
\hline 7 & VB14 & ORYLUX 4 & Interspecific & INERA & 47 & V30 & PL58-2 & O. glaberrima & AfricaRice \\
\hline 8 & VB15 & ORYLUX 2 & Interspecific & INERA & 48 & V31 & PL62-1 & O. glaberrima & AfricaRice \\
\hline 9 & VB17 & WAB 2066-WAT20-1-B-1-1 & Interspecific & INERA & 49 & V33 & PL67-1 & O. glaberrima & AfricaRice \\
\hline 10 & VB18 & $\begin{array}{l}\text { WAB 2066-6-FKR4-WAC1- } \\
\text { TGR1-B-WAT-B1 }\end{array}$ & Interspecific & INERA & 50 & V34 & PL68-1 & O. glaberrima & AfricaRice \\
\hline 11 & VB19 & WAB 2066-WAT21-1-B-1-TGR2 & Interspecific & INERA & 51 & V35 & PL68-6 & O. glaberrima & AfricaRice \\
\hline 12 & VB20 & SAHEL 309 & Interspecific & INERA & 52 & V36 & PL68-8 & O. glaberrima & AfricaRice \\
\hline 13 & VB21 & $\begin{array}{l}\text { WAB 2081-WAC2-2-TGR2- } \\
\text { WAT1-9-TGR3 }\end{array}$ & Interspecific & INERA & 53 & V37 & PL75-2 & O. glaberrima & AfricaRice \\
\hline 14 & VB22 & $\begin{array}{l}\text { WAB 2138-WAC B-2-TGR2- } \\
\text { WAT-B1 }\end{array}$ & Interspecific & INERA & 54 & V38 & PL75-3 & O. glaberrima & AfricaRice \\
\hline 15 & VB24 & NIL 16 & Interspecific & INERA & 55 & V39 & PL75-6 & O. glaberrima & AfricaRice \\
\hline 16 & VB25 & WAB 2066-WAT20-1-B-1-TGR1 & Interspecific & INERA & 56 & V40 & PL82-7 & O. glaberrima & AfricaRice \\
\hline 17 & VB26 & WAB 2066-WAT21-1-B-1-1 & Interspecific & INERA & 57 & V41 & PL85-1 & O. glaberrima & AfricaRice \\
\hline 18 & VB27 & $\begin{array}{l}\text { WAB 2066-6-FKR4-WAC1- } \\
\text { TGR1-B-WAT-B6 }\end{array}$ & Interspecific & INERA & 58 & V42 & PL85-2 & O. glaberrima & AfricaRice \\
\hline 19 & VB28 & WAB 2066-WAT20-1-B-1-TGR3 & Interspecific & INERA & 59 & V43 & PL85-3 & O. glaberrima & AfricaRice \\
\hline 20 & V1 & TOG5672 & O. glaberrima & AfricaRice $^{b}$ & 60 & V45 & PL85-5 & O. glaberrima & AfricaRice \\
\hline 21 & $\mathrm{~V} 2$ & TOG5681 & O. glaberrima & AfricaRice & 61 & V46 & PL87-1 & O. glaberrima & AfricaRice \\
\hline 22 & V3 & TOG7291 & O. glaberrima & AfricaRice & 62 & V47 & PL87-3 & O. glaberrima & AfricaRice \\
\hline 23 & V4 & $\mathrm{S} 2-4$ & O. glaberrima & AfricaRice & 63 & V48 & PL87-4 & O. glaberrima & AfricaRice \\
\hline 24 & V5 & S2-5 & O. glaberrima & AfricaRice & 64 & V49 & PL87-5 & O. glaberrima & AfricaRice \\
\hline 25 & V6 & S5-8 & O. glaberrima & AfricaRice & 65 & V50 & PL87-6 & O. glaberrima & AfricaRice \\
\hline 26 & V7 & S6-9 & O. glaberrima & AfricaRice & 66 & V51 & PL87-8 & O. glaberrima & AfricaRice \\
\hline 27 & V8 & S7-1 & O. glaberrima & AfricaRice & 67 & V52 & PL88-3 & O. glaberrima & AfricaRice \\
\hline 28 & V9 & S19-4 & O. glaberrima & AfricaRice & 68 & V53 & PL92-1 & O. glaberrima & AfricaRice \\
\hline 29 & V10 & S21-6 & O. glaberrima & AfricaRice & 69 & V54 & PL92-4 & O. glaberrima & AfricaRice \\
\hline 30 & V11 & S24-9 & O. glaberrima & AfricaRice & 70 & V56 & S19-3 & O. glaberrima & AfricaRice \\
\hline 31 & V12 & Pl 49-7 & O. glaberrima & AfricaRice & 71 & V57 & Moroberekan & O. sativa & INRAB \\
\hline 32 & V13 & PL50-4 & O. glaberrima & AfricaRice & 72 & V58 & CG14 & O. glaberrima & INRAB \\
\hline 33 & V15 & PL51-1 & O. glaberrima & AfricaRice & 73 & V60 & WAB 56-50 & O. sativa & INRAB \\
\hline 34 & V16 & PL51-2 & O. glaberrima & AfricaRice & 74 & V61 & ARICA 1 & Interspecific & INRAB \\
\hline 35 & V17 & PL51-3 & O. glaberrima & AfricaRice & 75 & V62 & ARICA 2 & Interspecific & INRAB \\
\hline 36 & V18 & PL 52-2 & O. glaberrima & AfricaRice & 76 & V63 & ARICA 3 & Interspecific & INRAB \\
\hline 37 & V19 & PL 52-4 & O. glaberrima & AfricaRice & 77 & V64 & ARICA 6 & Interspecific & INRAB \\
\hline 38 & V20 & PL 52-5 & O. glaberrima & AfricaRice & 78 & V66 & IR 64 & O. sativa & INRAB \\
\hline 39 & V21 & PL 52-7 & O. glaberrima & AfricaRice & 79 & V69 & NERICA L-19 & Interspecific & INRAB \\
\hline 40 & V22 & PL 52-8 & O. glaberrima & AfricaRice & & & & & \\
\hline
\end{tabular}

INERA, Institute of Environment and Agricultural Research of Burkina-Faso; INRAB, National Institute of Agricultural Research of Benin. anterspecific: Oryza glaberrima $\times$ O. sativa.

${ }^{\mathrm{b}}$ AfricaRice: Africa Rice Center (Benin). 
the effects of silicon on the reaction to the virus.

\section{Materials and Methods}

Plant materials. A total of 79 rice genotypes obtained from three research institutions were used for the study: 51 from AfricaRice (Benin Republic); 9 from the National Institute of Agricultural Research of Benin (INRAB), and 19 from the Institute of Environment and Agricultural Research (INERA) of Burkina-Faso (Table 1). These genotypes included three $O$. sativa, four $O$. glaberrima, 24 interspecific rice varieties and 48 intraspecific $O$. glaberrima genotypes. Most of the interspecific rice are aromatic, and some of these have been released to rice farmers in West Africa (Wopereis, 2013). Two rice genotypes among the collections served as checks and these are IR64 (O. sativa; susceptible check) and TOG5681 (O. glaberrima; resistant check).

Source of RYMV inoculum. The 79 genotypes were screened using the most virulent RYMV isolate (RBe24) collected from northern-Benin Republic (Agnoun, 2013). The isolate belongs to the S1 serological diversity group, which is the most widespread in all the major rice growing areas of the country (Oludare et al., 2016).

Green house experiments. Two experiments were conducted in 2017 under screen house conditions at the AfricaRice-Benin station located in the Abomey Calavi District. The first experiment was from May to July while the second was from September to November. Plastic pots of $1 \mathrm{~L}$ capacity were filled with heat-sterilized soil. The experiment was a factorial involving three factors viz. genotypes, inoculation treatment (inoculated vs. non-inoculated) and silicon dose applied $(0,5$, and $10 \mathrm{~g} / \mathrm{plot})$. In each case, experimental design was randomized complete block with two replications. Two to three rice seeds were sown per pot and seedlings were thinned to one plant per pot. The silicon was supplied as Calcium Silicate $\left(\mathrm{CaSiO}_{3}\right)$ at sowing. In addition, plants were fertilized with $1 \mathrm{~g}$ of NPK 15-15-15 per pot at sowing and $0.2 \mathrm{~g}$ of urea $(46 \%$ of $\mathrm{N})$ per pot at 21 and 42 days after sowing. The pots were watered and weeded regularly throughout the duration of the experiments.

Inoculation of rice plants and enzyme-linked immunosorbent assay test. The RBe24 isolate of RYMV was obtained from the Plant Pathology Unit of AfricaRice, Benin. To obtain fresh inoculum, the isolate was propagated on the susceptible $O$. sativa rice variety IR64 following the procedure described by Fargette et al. (2002) and Oludare et al. (2016). The fresh infected leaves obtained were ground in phosphate buffer $(0.01 \mathrm{M} \mathrm{pH} 7.0)$ at a ratio of $1: 10(\mathrm{w} / \mathrm{v}) ; 0.5 \mathrm{~g}$ carborundum $(600-\mathrm{mesh})$ was added to the inoculum sap to increase the efficiency of the mechanical inoculation of the virus into leaves tissues (Pinel-Galzi et al., 2018). The viral solution was manually rubbed on the leaves of 21-day-old seedlings, from the base to the top of the plant. Indirect antigen-coated-plate enzyme-linked immunosorbent assay (ELISA) was performed on leaf samples collected at 42 days after inoculation (DAI) using the methodology described by Oludare et al. (2016).

Data collection. RYMV symptoms were assessed at 21 and 42 DAI on a scale of 0 to 9 (International Rice Research Institute, 2002) where ' 0 ' represents normal plant growth with no visible symptoms and ' 9 ' represents severe leaves symptoms or plant death (Fig. 1). In addition, data were collected on plant height, number of tillers and number of leaves at 21 and 42 DAI. Disease symptoms scores recorded at 21 and 42 DAI were used to calculate disease incidence (DI) and disease severity (DS) as follows:

Disease incidence (DI) $=$ Total number of leaves with symptoms $\times 100 /$ Total number of leaves

Disease severity $(\mathrm{DS})=\{((\mathrm{n} 1 \times 1)+(\mathrm{n} 3 \times 3)+(\mathrm{n} 5 \times 5)$ $+(\mathrm{n} 7 \times 7)+(\mathrm{n} 9 \times 9)) \times 100 /((\mathrm{n} 1+\mathrm{n} 2+\mathrm{n} 3+\mathrm{n} 5+\mathrm{n} 7+\mathrm{n} 9)$ $\times 9$ \}, where, $\mathrm{n} 1, \mathrm{n} 3, \mathrm{n} 5, \mathrm{n} 7$, and $\mathrm{n} 9$ represent the number of leaves scored $1,3,5,7$, and 9 , respectively;

Statistical analysis. Data were analyzed using Excel and JMP 12.01 (SAS Institute, Cary, NC, USA). Analysis of
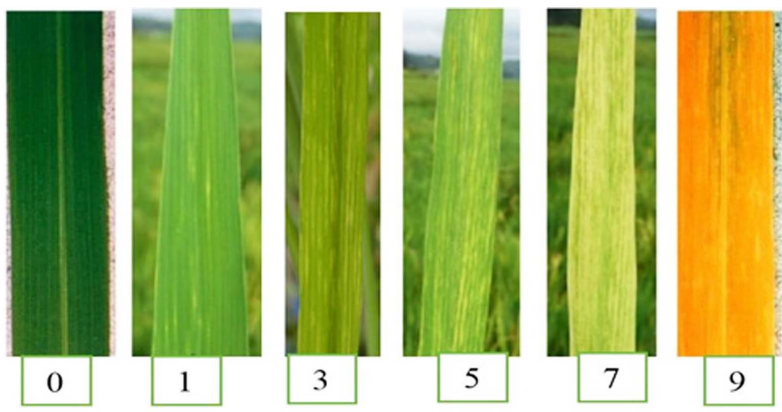

Fig. 1. Symptoms of rice yellow mottle virus corresponding to the 0 to 9 scoring scale (International Rice Research Institute, 2002; Koudamiloro et al., 2015). 0, no symptom observed; 1 , leaves greens, little yellow sparse dots or streaks; 3 , leaves greens, abundant dots or streaks, $<5 \%$ height reduction; 5 , leaves pale green with mottling, 6-25\% height reduction, flowering slightly delayed; 7, leaves pale yellow with mottling, $26-75 \%$ height reduction, flowering delayed; 9, leaves turned yellow or orange, $>75 \%$ height reduction, no flowering, plant dead. 
variance (ANOVA) was carried out to determine if the differences among genotypes and silicon doses, inoculation treatments and interactions among the main effects were significant. Turkey's honestly significant difference test was then used to compare means of the inoculated plants with the control for significance. Principal component analysis (PCA) and Hierarchical Clustering were used to group the genotypes on the basis of their level of resistance to isolate $\mathrm{RBe} 24$ of the virus.

\section{Results}

Incidence and severity of RYMV symptoms on rice. Typical symptoms of RYMV were observed on the in- oculated rice plants in both experiments. Infected plants exhibited yellow discoloration, necrosis and mottling of rice leaves. Severe symptoms manifested as stunting, and in some cases death of the plants. Differences among the 79 genotypes evaluated for DI and DS were significant ( $P$ $<0.001$ ) at 21 and 42 DAI (Table 2). DI for the susceptible IR64 was $100 \%$ at 21 and 42 DAI, but severity was $48.2 \%$ and $50.9 \%$ at 21 and 42 DAI, respectively (Table 3 ). Three genotypes had disease severity values higher than that of IR64 at 42 DAI; these were ARICA 6 (V64) with DS of $61.3 \%$, WAB 2081-WAC2-2-TGR2-WAT1-9-TGR3 (VB21) with DS of $61.7 \%$ and PL 52-2 (V18) with a DS of $66.5 \%$. In contrast, the DI and the DS for the resistant check was 0 at 21 and 42 DAI. Averaged over the 79 geno-

Table 2. Analysis of variance test performed on the disease incidence and disease severity at 21 and 42 DAI

\begin{tabular}{|c|c|c|c|c|c|c|c|c|c|}
\hline \multirow{3}{*}{ Source of variation } & \multirow{3}{*}{$\begin{array}{l}\text { Degree of } \\
\text { freedom }\end{array}$} & \multicolumn{4}{|c|}{$21 \mathrm{DAI}$} & \multicolumn{4}{|c|}{$42 \mathrm{DAI}$} \\
\hline & & \multicolumn{2}{|c|}{ Disease incidence } & \multicolumn{2}{|c|}{ Disease severity } & \multicolumn{2}{|c|}{ Disease incidence } & \multicolumn{2}{|c|}{ Disease severity } \\
\hline & & $\begin{array}{l}\text { Mean } \\
\text { square }\end{array}$ & F-value & $\begin{array}{l}\text { Mean } \\
\text { square }\end{array}$ & F-value & $\begin{array}{l}\text { Mean } \\
\text { square }\end{array}$ & F-value & $\begin{array}{l}\text { Mean } \\
\text { square }\end{array}$ & F-value \\
\hline Block & 1 & $13,169.6$ & $26.4^{* * *}$ & $3,835.5$ & $26.1 * * *$ & $2,727.3$ & $4.2^{*}$ & 98 & $0.5 \mathrm{~ns}$ \\
\hline Dose (of silicon) & 2 & 297.6 & $0.6 \mathrm{~ns}$ & 134.4 & $0.9 \mathrm{~ns}$ & $1,017.6$ & $1.6 \mathrm{~ns}$ & 157.2 & $0.8 \mathrm{~ns}$ \\
\hline Genotype & 78 & $10,412.8$ & $20.9 * * *$ & $2,736.0$ & $18.6^{* * *}$ & $9,525.2$ & $14.6^{* * *}$ & $2,616.7$ & $12.8 * * *$ \\
\hline Dose $($ of silicon $) \times$ Genotype & 156 & 268.9 & $0.5 \mathrm{~ns}$ & 78.6 & $0.5 \mathrm{~ns}$ & 330.6 & $0.5 \mathrm{~ns}$ & 133.8 & $0.7 \mathrm{~ns}$ \\
\hline Error & 236 & 499.0 & & 147.0 & & 653.8 & & 204.1 & \\
\hline Total & 473 & & & & & & & & \\
\hline
\end{tabular}

Significant at $* P<0.05$ and $* * * P<0.001$, respectively; ns, non-significant.

DAI, days after inoculation.

Table 3. Means of inoculation and non-inoculation treatments for agronomic traits at 21 and 42 days after inoculation

\begin{tabular}{|c|c|c|c|c|c|c|c|}
\hline $\begin{array}{l}\text { Days after } \\
\text { inoculation }\end{array}$ & Treatments & Means & $\begin{array}{l}\text { Plant height } \\
\text { (cm) }\end{array}$ & $\begin{array}{l}\text { No. of tillers } \\
\text { (count/plant) }\end{array}$ & $\begin{array}{l}\text { No. of leaves } \\
\text { (count/plant) }\end{array}$ & $\begin{array}{c}\text { Disease incidence } \\
(\%)\end{array}$ & $\begin{array}{c}\text { Disease severity } \\
(\%)\end{array}$ \\
\hline \multirow[t]{6}{*}{21} & Non-inoculated & Overall & $92.2 \pm 0.6 \mathrm{a}$ & $4.2 \pm 0.1 \mathrm{a}$ & $15.6 \pm 0.2 \mathrm{a}$ & - & - \\
\hline & & TOG5681 & 79.2 & 4.7 & 14.3 & - & - \\
\hline & & IR64 & 87.0 & 8.2 & 30.5 & - & - \\
\hline & Inoculated & Overall & $73.8 \pm 0.6 b$ & $3.4 \pm 0.1 \mathrm{~b}$ & $11.7 \pm 0.2 b$ & $59.5 \pm 2.1$ & $29.2 \pm 1.1$ \\
\hline & & TOG5681 & 74.5 & 3.8 & 12.5 & 0 & 0 \\
\hline & & IR64 & 55.8 & 4.5 & 16.2 & 100.0 & 48.2 \\
\hline \multirow[t]{6}{*}{42} & Non-inoculated & Overall means & $110.4 \pm 1.4 \mathrm{a}$ & $5.9 \pm 0.2 \mathrm{a}$ & $26.9 \pm 0.4 \mathrm{a}$ & - & - \\
\hline & & TOG5681 & 116.7 & 7.7 & 35.8 & - & - \\
\hline & & IR64 & 94.2 & 9.8 & 48.5 & - & - \\
\hline & Inoculated & Overall & $94.0 \pm 1.3 \mathrm{~b}$ & $6.7 \pm 0.2 \mathrm{~b}$ & $26.6 \pm 0.4 \mathrm{a}$ & $61.9 \pm 2.1$ & $29.2 \pm 1.1$ \\
\hline & & TOG5681 & 110.3 & 8.8 & 35.0 & 0 & 0 \\
\hline & & IR64 & 78.5 & 8.2 & 36.3 & 100.0 & 50.9 \\
\hline
\end{tabular}

Means within each day after inoculation followed by the same letter are not significantly different according to honestly significant difference test of Turkey at $5 \%$ level of probability. 


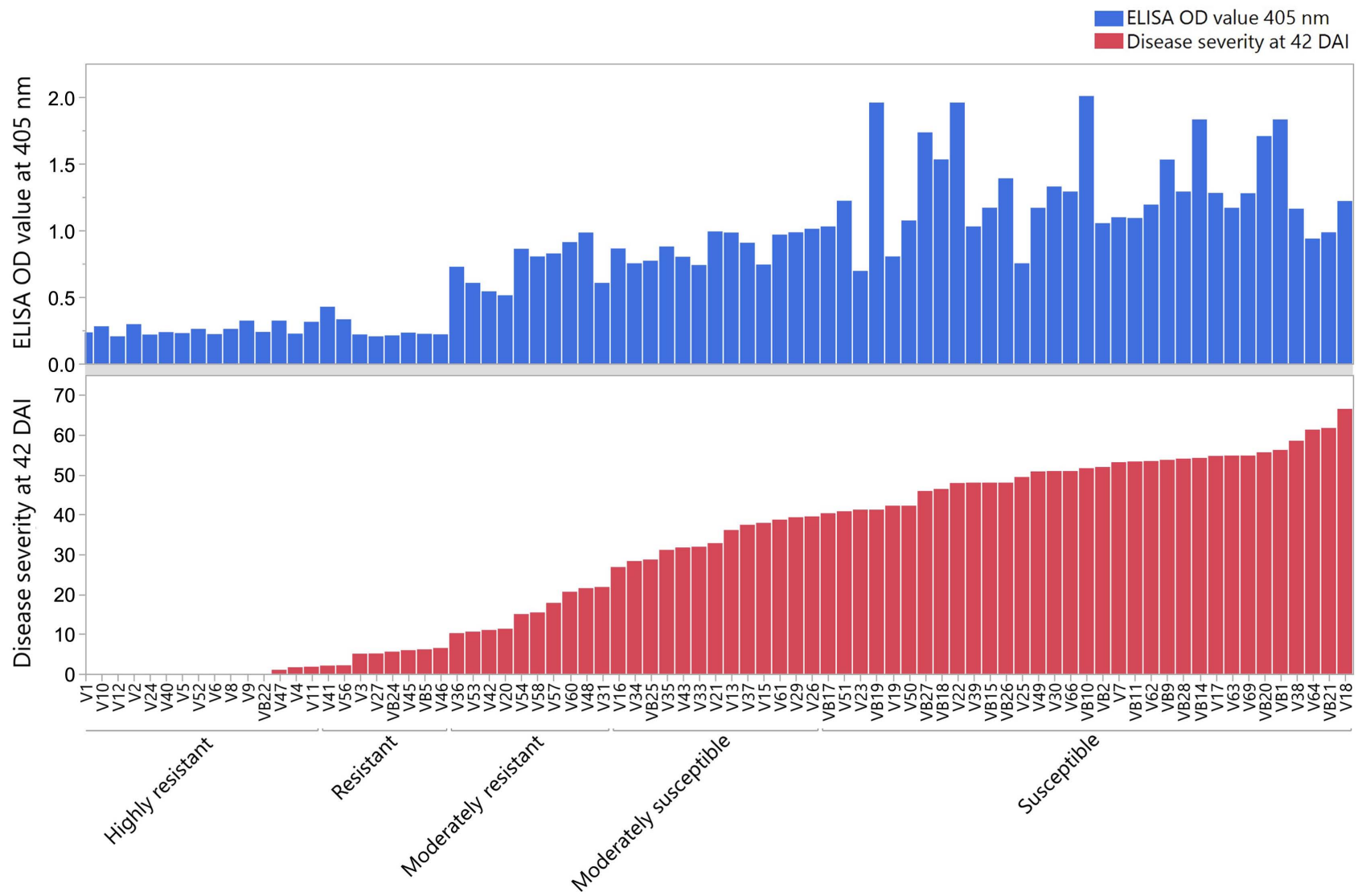

Fig. 2. Classification of tested rice genotypes for their resistance to rice yellow mottle virus (RYMV) using the disease severity score (DS) at 42 days after inoculation (DAI) and enzyme-linked immunosorbent assay (ELISA) optical density value measured for the tested rice genotypes at 42 DAI. Rice materials were categorized as follow based on the disease severity: susceptible, $40 \%$ and above; moderately susceptible, DS = 26-39\%; moderately resistant, DS = 10-25\%; resistant, DS = 2-9\%; highly resistant, DS <2. ELISA OD value at 405 $\mathrm{nm}$, ELISA optical density value measured at absorbance of $405 \mathrm{~nm}$ after $3 \mathrm{~h}$ of incubation with para NitroPhenylPhosphate tablets dissolved in $1 \times$ phosphate buffer saline Tween $(1 \mathrm{mg} / \mathrm{ml})$.

types, DI increased from $59.5 \%$ at 21 DAI to $61.9 \%$ at 42 DAI, while average DS was unchanged from 21 DAI to 42 DAI (Table 3). On the basis of the DS score at 42 DAI, the 79 genotypes were grouped into five viz. highly resistance (DS score $<2 \%$ ), resistant (DS score $=2-9 \%$ ), moderately resistant (DS score $=10-25 \%$ ), moderately susceptible (DS score $=26-39 \%$ ), susceptible (DS score $>40 \%$ ). The numbers of genotypes in these groups were $15,8,10,13$, and 33, respectively (Fig. 2). When the average DS of the two most resistant groups (highly resistant and resistant) was compared to that of the two susceptible groups (susceptible and moderately susceptible), a major difference was observed. The average DS of the resistant groups (comprising 23 genotypes) was 1.1 and $2.2 \%$ at 21 and 42 DAI in contrast to 48.8 and $51.0 \%$ at 42 DAI for the susceptible groups (a total of 46 genotypes). The highest DS at 42 DAI were recorded for the genotypes VB21 (61.7\%), V64 (61.3\%), and V18 (66.5\%).
Effects of RYMV on agronomic traits of rice. RYMV significantly $(P<0.001)$ affected the height, the number of tillers and the number of leaves of the rice plant at 21 DAI (Table 4). At this time, reduction in the plant height due to RYMV ranged from $5.9 \%$ for TOG5681 to $35.9 \%$ for IR64 and averaged 19.9\%. Reductions, which ranged from $19.1 \%$ to $45.1 \%$ for the number of tillers, and $12.6 \%$ to $46.9 \%$ for the number of leaves averaged $19.0 \%$ and $25.0 \%$, respectively. Inoculum $\times$ genotype interaction was significant $(P<0.001)$ for plant height, number of tillers and number of leaves at $21 \mathrm{DAI}$, indicating that the genotypes differed in their response patterns to inoculation treatments at this time.

At 42 DAI, overall plant height reduction was $14.9 \%$ (range, 5.5 to 16.7), a somewhat lower value than the reduction at 21 DAI (Table 3); this reduction was, however, significant (Table 4). Different from the general trend of the result at $21 \mathrm{DAI}$, the average number of tillers was 


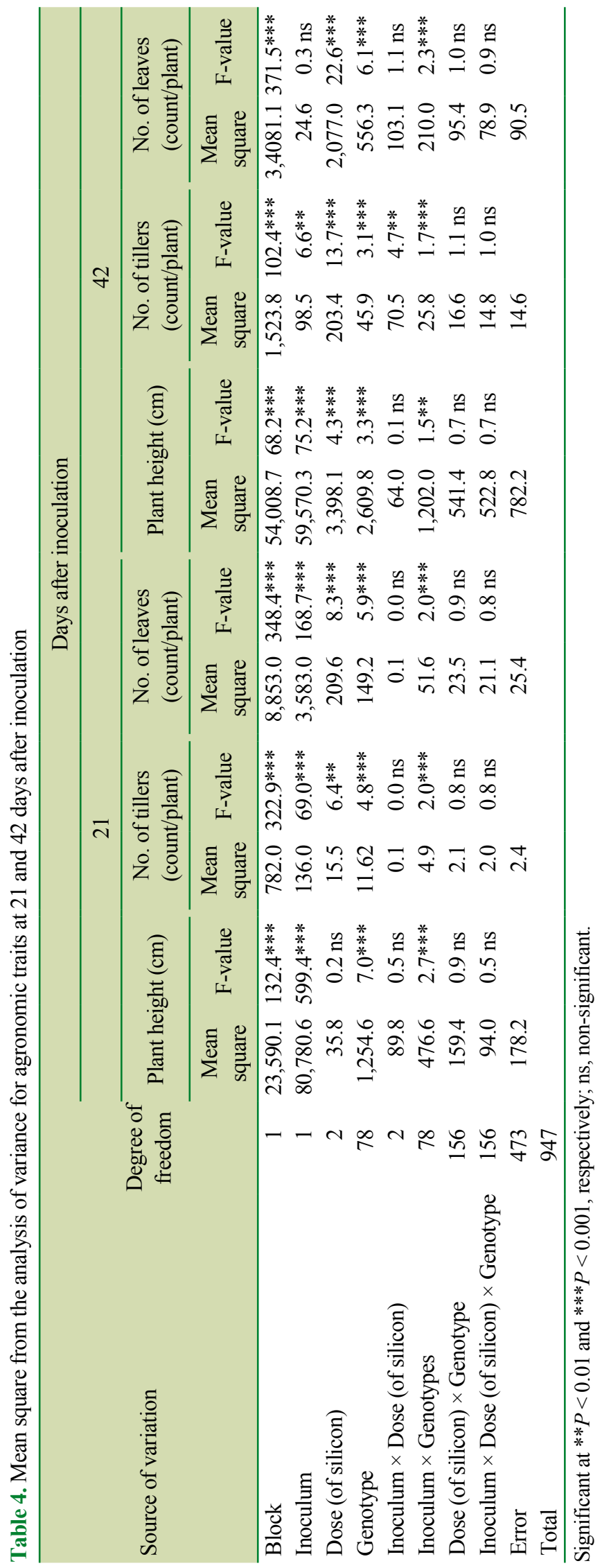

significantly lower (13.6\%) in non-inoculated pots than in inoculated pots. Difference in number of leaves between plants in infected and non-infected pots was not significant (Table 4). As with the results obtained at 21 DAI, differences in response patterns of the rice genotypes to RYMV infection at 42 DAI were significant. This was evidenced by the significant inoculum $\times$ genotype interaction (Table 4).

At 42 DAI, when the differences in symptoms among the inoculated genotypes were highest; the serological tests from ELISA, using leaves, confirmed the former. Optical density (OD) values (measured at absorbance of $405 \mathrm{~nm}$ ) varied from 0.1 to 2.0 for the 79 genotypes. Nine genotypes which showed no visible symptoms and had no or very low virus load in their leaf samples were more resistant than TOG5681 (Fig. 2); these included PL55-7 (V24), S7-1 (V8) and S19-4 (V9), in that order. Genotypes considered susceptible with DI value of $100 \%$ had an OD values as high as 2.0 (Fig. 2). The highest OD value measured at absorbance of $405 \mathrm{~nm}$ (Fig. 2), were recorded for the genotypes VB19 (1.9), V22 (1.9), and VB10 (2.0).

Effects of silicon on DS and agronomic traits of RYMVinfected and non-infected rice plants. The application of silicon did not significantly influence the DI and DS of RYMV at 21 and 42 DAI (Table 2). Silicon dose x genotype interaction was also not significant for both DI and DS at 21 and 42 DAI (Table 2). The effect of silicon on rice plants manifested on the number of tillers and the number of leaves as early as $21 \mathrm{DAI}(P<0.01$ to $P<0.001)$ but the effect was not significant for the plant height at this time (Table 2). The effect of silicon on the three traits was significant at $42 \mathrm{DAI}(P<0.05$ to $P<0.001)$ (Table 4). Plant height at $42 \mathrm{DAI}$ showed linear increase from $0 \mathrm{~g} \mathrm{CaSiO}_{3} /$ plant to $10 \mathrm{~g} \mathrm{CaSiO}_{3} /$ plant for plants in non-inoculated and inoculated pots. In non-inoculated pots, plant height at $5 \mathrm{~g}$ $\mathrm{CaSiO}_{3} /$ plant and $10 \mathrm{~g} \mathrm{CaSiO}_{3} /$ plant increased by $1.9 \%$ and $4.9 \%$ over the height of plants in pots to which silicon was not applied (Fig. 3). In the inoculated pots, corresponding increases in the height of plants at these rates over those of plants in pots without silicon were $3.6 \%$ and $6.3 \%$, respectively (Fig. 3).

The effect of silicon on the number of tillers and number of leaves was best demonstrated at 42 DAI, and the response patterns for both traits were similar and in contrast to the increases with rate observed for plant height. In effect, silicon reduced the number of tillers and number of leaves produced by rice plants in both inoculated and non-inoculated pots (Fig. 3).

Silicon dose $\times$ inoculation treatment was not significant 


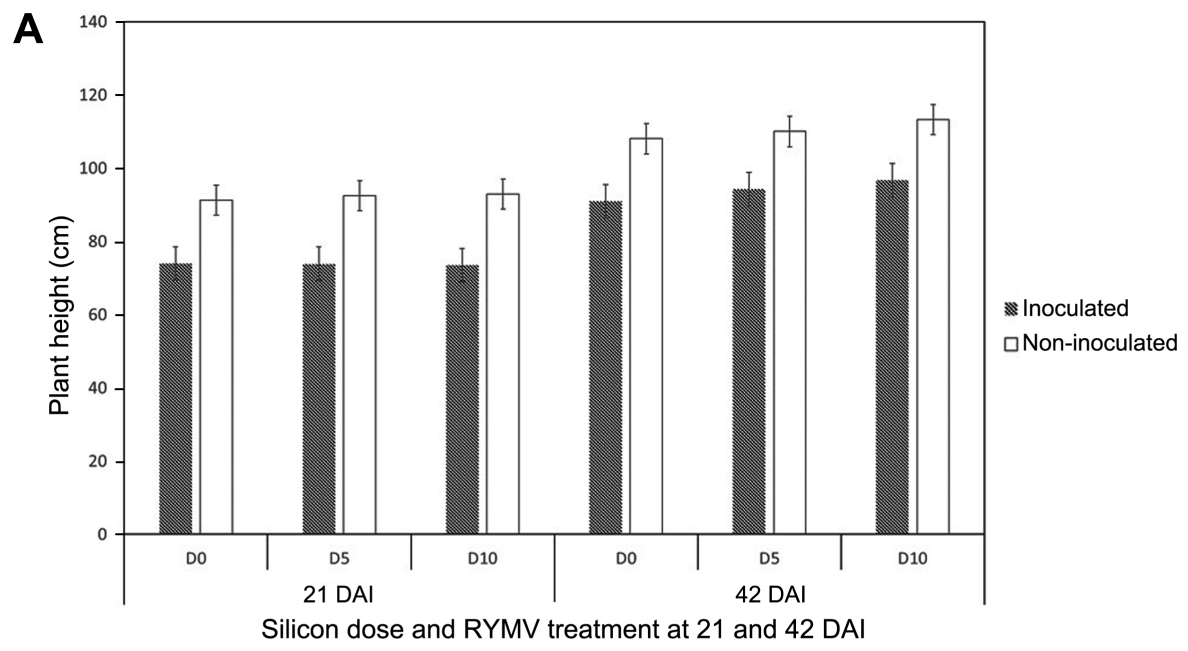

B

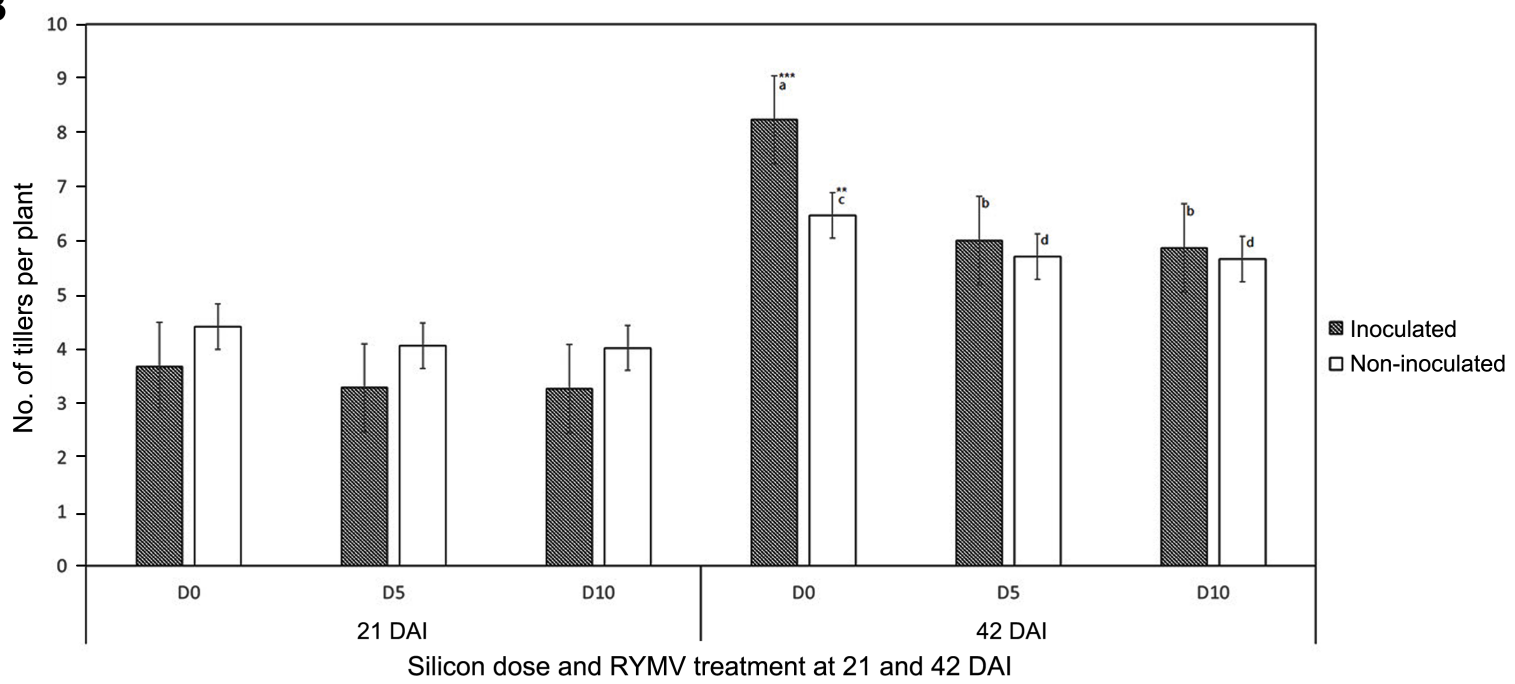

C

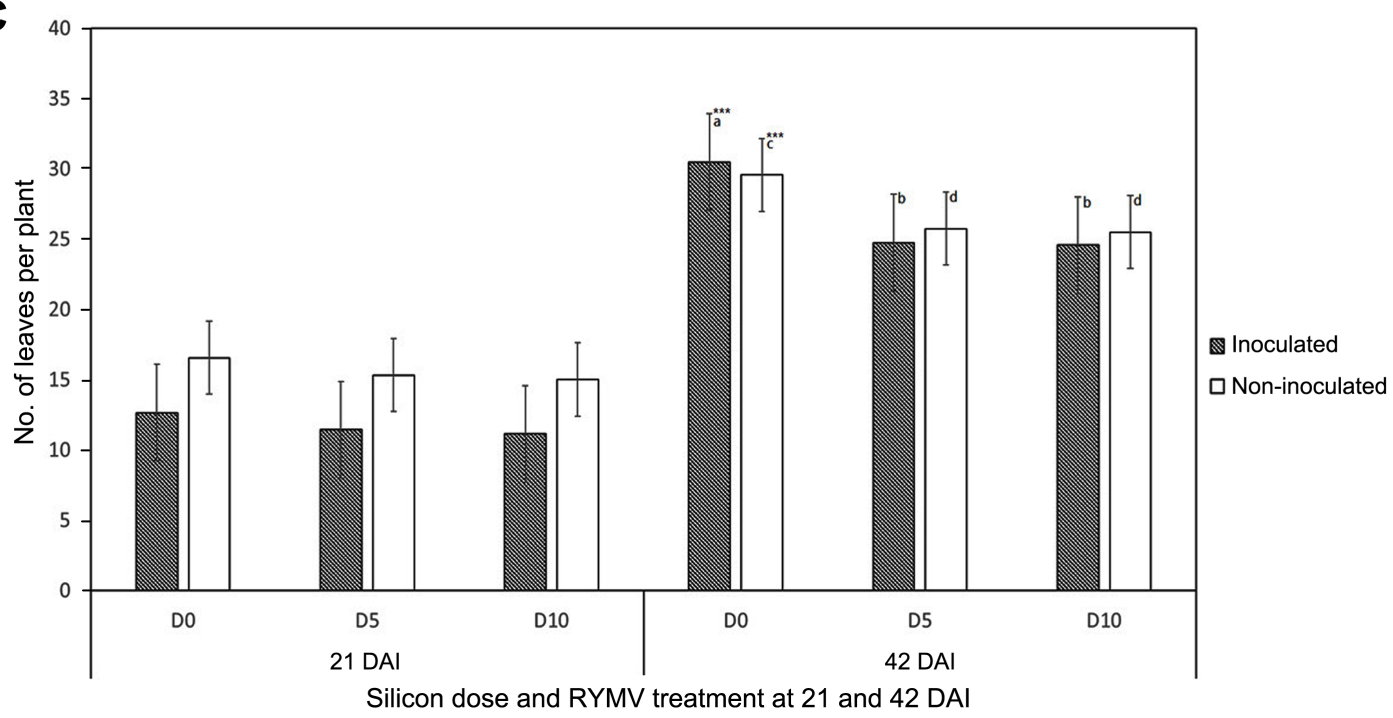

Fig. 3. Plant height (A), number of tillers (B), and number of leaves (C) at 21 and 42 days after inoculation (DAI) of inoculated and noninoculated rice plants at three silicon levels. $\mathrm{D} 0,0 \mathrm{~g}$ of $\mathrm{CaSiO}_{3} /$ plant; D5, $5 \mathrm{~g}$ of $\mathrm{CaSiO}_{3} /$ plant; D10, $10 \mathrm{~g}$ of CaSiO$/ \mathrm{plant}_{3} \mathrm{RYMV}$, rice yellow mottle virus. For inoculated and non-inoculated plants at $42 \mathrm{DAI}$, means followed by the same letter are not significantly different according to honestly significant difference test of Turkey at 5\% level or probability. ***Significant at $P<0.001, * *$ Significant at $P$ $<0.01$. 
for the three agronomic traits at $21 \mathrm{DAI}$ while it was significant for only number of tillers at 42 DAI. This result indicates that the effect of silicon on number of tillers produced at 42 DAI was influenced by the RYMV infection status of the plant. In comparison with pots to which silicon was not applied, the reduction was $12.3 \%$ for both 5 and $10 \mathrm{~g}$ $\mathrm{CaSiO}_{3} /$ plant for number of tillers in non-inoculated pots while the reductions in number of tillers were $26.8 \%$ for 5 $\mathrm{g} \mathrm{CaSiO}_{3} /$ plant and $28 \%$ at $10 \mathrm{~g} \mathrm{CaSiO}_{3} /$ plant for number of tillers in inoculated pots, respectively (Fig. 3).

Silicon dose $\mathrm{x}$ genotype interaction for the traits was not significant at $21 \mathrm{DAI}$ and $42 \mathrm{DAI}$. In effect, the genotypes did not differ in the response pattern of their agronomic traits to silicon application. The inoculum $\times$ silicon dose $\times$ genotype interaction was not significant for any of the three traits at these times.

PCA and hierachical clustering of $\mathbf{7 9}$ rice genotypes. The PCA biplot (Fig. 4) showed that resistant genotypes

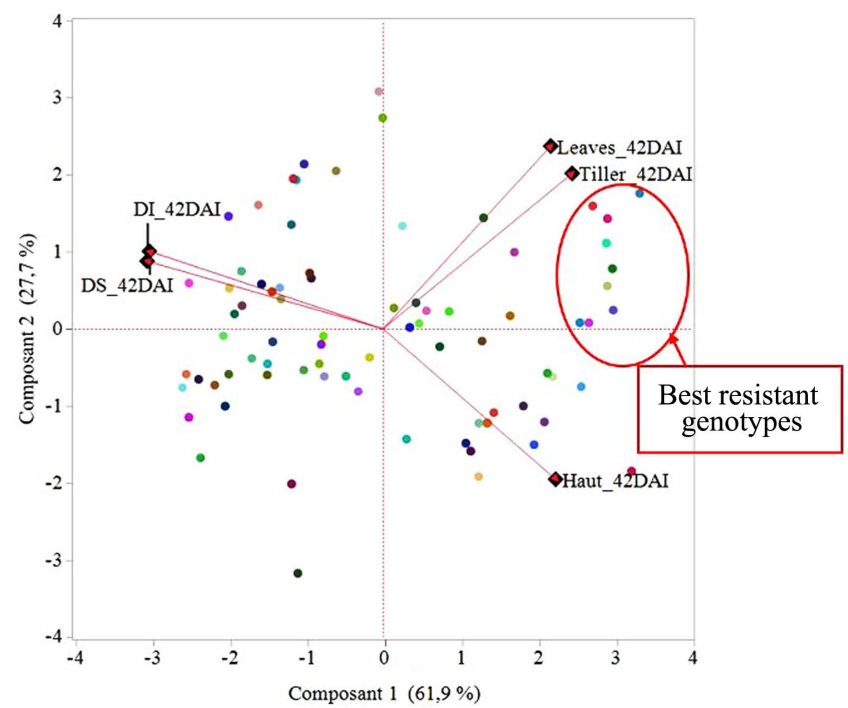

Fig. 4. Principal component analysis biplot of the 79 rice genotypes based on measured parameters. Haut, height; 42DAI, 42 days after inoculation; DI, disease incidence; DS, disease severity.

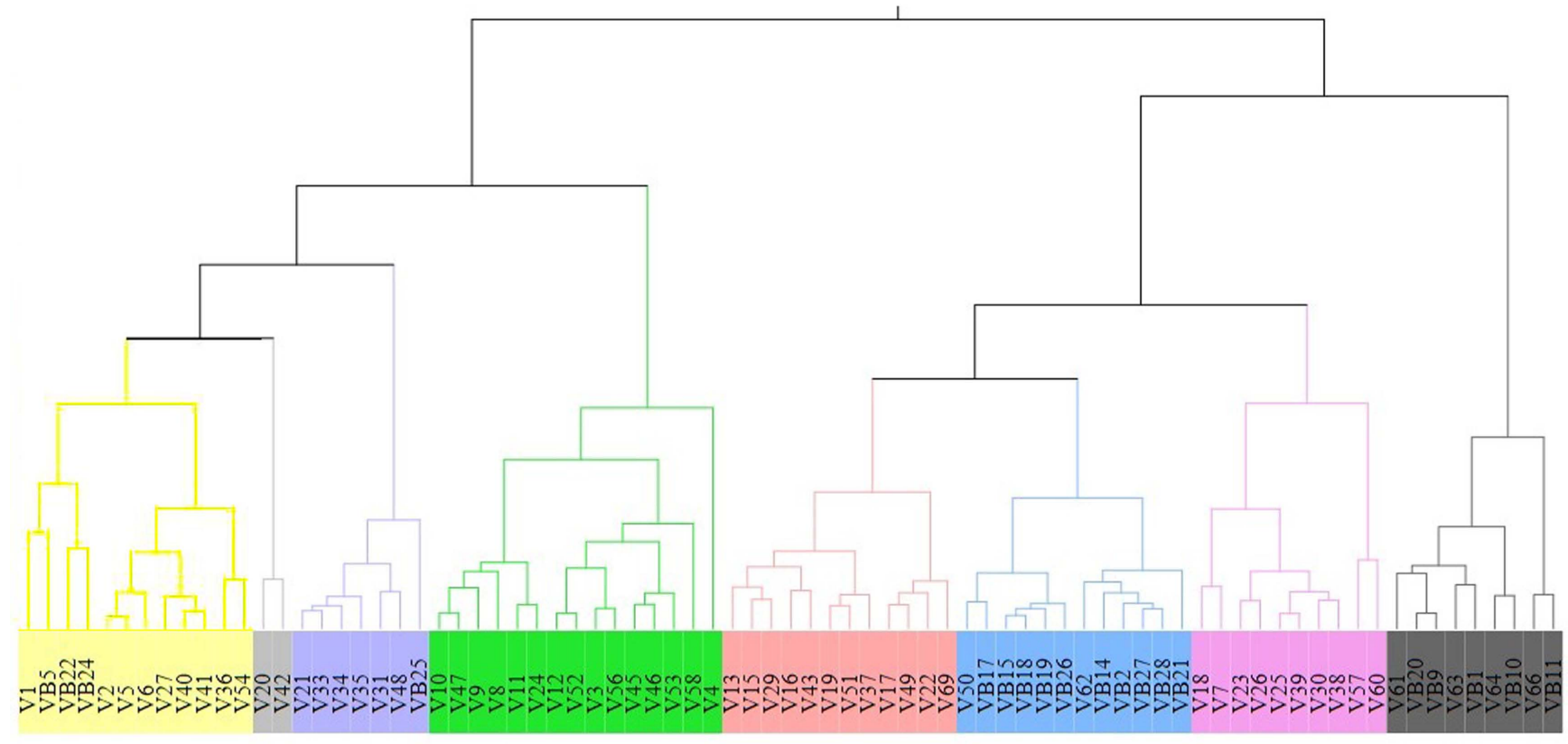

From the left (pale yellow clade) to the right (dark grey) the differences between cluster are summarized viz.

\begin{tabular}{ccccccc}
\hline \multicolumn{7}{c}{ Means of agronomic and disease traits at 42 days after inoculation } \\
\hline Cluster & $\begin{array}{c}\text { Genotypes } \\
\text { (Count) }\end{array}$ & Disease severity & Disease incidence & Plant height & Plant tiller & Plant leave \\
\hline 1 & 12 & 2.7 & 7.2 & 108.5 & 9.6 & 37.0 \\
2 & 2 & 11.2 & 30.7 & 113.4 & 9.2 & 30.0 \\
3 & 7 & 22.7 & 57.7 & 106.5 & 7.4 & 30.7 \\
4 & 15 & 3.8 & 11.8 & 113.9 & 6.2 & 25.6 \\
5 & 12 & 36.5 & 73.6 & 104.5 & 5.5 & 23.5 \\
6 & 12 & 49.7 & 100 & 88.1 & 5.4 & 24.1 \\
7 & 10 & 46.6 & 96.3 & 100.8 & 3.9 & 17.7 \\
8 & 9 & 51.8 & 99.7 & 84.6 & 7.8 & 34.7 \\
\hline
\end{tabular}

Fig. 5. Dendrogram of the 79 rice genotypes based on measured parameters at 42 days after inoculation. 
that exhibited high number of tillers and leaves with moderate plant height, had low score of DS and DI. The hierarchical clustering (Fig. 5) based on the measured parameters showed agreement with the PCA (Fig. 4) and differentiated the genotypes into eight groups based on the agro-morphological traits and physiological mechanism of the defense responses. The most resistant group (Cluster 1) contained the best nine genotypes viz. V1 (TOG5672), VB5 (WAB 2152-TGR2-WAT1-2), VB22 (WAB 2138-WAC B2-TGR2WAT-B1), V2 (TOG5681), V5 (S2-5), V6 (S5-8), V27 (S2-6), V40 (PL82-7), and V41 (PL85-1). This cluster (Fig. 5) exhibited low average DS (2.7\%) and DI (7.2\%), with moderate plant height $(108.5 \mathrm{~cm})$, tillers $(9.6)$, and the number of leaves (37.0) at $42 \mathrm{DAI}$ in contrast to the most susceptible group (Cluster 8) (Fig. 5) which showed high DS (51.8\%) and DI (99.7\%), with average agro-morphological parameters at 42 DAI viz. plant height $(84.6 \mathrm{~cm})$, tillers (7.8) and the number of leaves (34.7). The highly resistant group (Cluster 1) included the resistant control TOG5681 while the susceptible control IR64 featured in the most susceptible group (Cluster 8).

\section{Discussion}

The present study identified many genotypes that showed effective resistance, confirmed by low DS and low ELISA titre values at $42 \mathrm{DAI}$, to RBe24 isolate of RYMV - the most pathogenic strain on the virus in Benin. An indication of the effectiveness of the resistance in these lines was the disparity in DS score of the two most resistant groups and the two most susceptible groups. The number of highly resistant (15) and resistant (8) genotypes indicate the likelihood of developing broad-based resistance to RYMV from these sources. The consistent high incidence, DS as well as high ELISA titre value for IR64, demonstrate the effectiveness of the inoculation technique, and provide strong evidence of the reliability of the results obtained in this study. The close DS values of IR64 at 21 (48.2\%) and 42 DAI (50.1\%) indicate that reaction of rice genotypes to RYMV can be reliably assessed at 21 DAI using the inoculation technique deployed in the present study. The results of our study demonstrate $O$. glaberrima to have high frequency of resistance alleles to RYMV. This is in agreement with the results of Pidon et al. (2020) that O. glaberrima is an invaluable source of resistance to RYMV in rice. In our study, this was evidenced by the composition of the highly resistant and resistant groups. The highly resistant group consisted of two $O$. glaberrima, $1 O$. glaberrima $\times$ $O$. sativa interspecific genotypes and 12 intraspecific $O$. glaberrima genotypes. Respective values for the resistant group were 1, 2, and 5. O. glaberrima germplasm is considered critical in developing a comprehensive strategy for the control of RYMV in West Africa (Orjuela et al., 2013; Pidon et al., 2017, 2020). Information on the resistance gene(s) present in these genotypes will be useful for designing a breeding strategy to pyramid them.

RYMV reduced plant height and number of tillers at the initial stage of plant growth $(21 \mathrm{DAI})$. In contrast to the reduction in plant height due to RYMV at $42 \mathrm{DAI}$, number of tillers, however, increased, indicating that infected plants showed some recovery from the effects of RYMV with age. Plant height and number of tillers are major yield components in rice (Akinwale et al., 2011; Huang et al., 2013; Li et al., 2019; Moldenhauer et al., 2004; Sakamoto and Matsuoka, 2008). Resistant genotypes used in this study also had high number of tillers and moderate plant height.

Although yield was not determined in the present study, the reduction in plant height and increase in the number of tillers under RYMV mirror the likely effects RYMV have on these traits, since plant height and number tillers are important yield components. Agahi et al. (2007) and Oladosu et al. (2018) reported a correlation of 0.6 and 0.7 between number of tillers and grain yield in rice. In general, the rice genotypes used in our study responded to RYMV infection by mitigating the effects of the virus. An indication of this was the lower percentage reduction observed for plant height at 42 DAI compared to $21 \mathrm{DAI}$, and the $13.6 \%$ increase in the number 0 of tillers at 42 DAI relative to the $19.0 \%$ reduction in number of tillers at 21 DAI. The significant inoculum $\times$ genotype interaction observed for plant height and number of tillers at 42 DAI indicate that plant response under non-inoculated condition was not indicative of performance under RYMV infection. Consequently, an effective inoculation technique is crucial for breeding progress.

Integrated management, with host plant resistance as an important component, is usually more effective in the control of many pests and diseases. Although, several authors have investigated the beneficial effects of Si treatment in mitigating various biotic and abiotic stresses in plants (Datnoff et al., 2007; Dufey et al., 2014; Mbonankira, 2014), our study was the first to investigate the effects of Si on RYMV in rice. Epstein (1994) and Abed-Ashtiani et al. (2012) reported that the supply of soluble Si and its accumulation provide stronger and tougher cell walls that act as mechanical barrier to viruses in vegetables. In the present study, we did not find any effect of Si on RYMV infection and DS. Similar to our results, Zellner et al. (2011) reported that high levels of $\mathrm{K}_{2} \mathrm{SiO}_{3}$ had no effect on tobacco mosaic virus. Si supplementation in Cucumber infected 
with Papaya ring spot virus, however, reduced to a larger extent the severity of this virus as well as its accumulation in the leaves (Elsharkawy and Mousa, 2015; Sakr, 2016). In contrast to these results, Bengsch et al. (1989) demonstrated that silicon application increased the incidence Belladonna mottle virus in infected tobacco plants. Sakr (2016) and Zellner et al. (2011) suggested that silicon effect may be virus-specific.

In this study, Si enhanced the plant height of rice in both inoculated and non-inoculated pots, with the highest percentage increases obtained at $10 \mathrm{~g} \mathrm{CaSiO}_{3}$ per plant, and with higher increase obtained in inoculated compared to non-inoculated pots. These results indicate that in terms of height, rice plants infected with RYMV benefitted more from $\mathrm{Si}$ application than non-inoculated plots. However, $\mathrm{Si}$ reduced the number of tillers in both inoculated and noninoculated pots, with much higher reductions in inoculated pots $\left(26.8 \%\right.$ and $28.0 \%$ at 5 and $10 \mathrm{~g} \mathrm{CaSiO}_{3}$ per plant, respectively) compared to non-inoculated pots $(12.3 \%$ at both 5 and $10 \mathrm{~g} \mathrm{CaSiO}_{3}$ per plant). These results indicate a major difference in the effects of Si on two major yield components in rice. Although grain yield was not determined in the present study, the reduction in number of tillers per plant suggests reduction in yield due to Si. Agahi et al. (2007) and Oladosu et al. (2018) reported a correlation of 0.6 and 0.7 between number of tillers and grain yield in rice. Kumar et al. (2011), Kumar and Nilanjaya (2014), and Sharifi (2018) from path analysis, also reported a direct effect of number of tillers on rice yield. The reductions of the $\mathrm{Si}$ dose on number of tillers was genotype-independent. This was indicated by the non-significant $\mathrm{Si}$ dose $\times$ genotype interaction, a result that suggests that both resistant and susceptible genotypes expressed similar responses.

Narayanaswamy et al. (2012), who studied the effect of $\mathrm{Si}$ on wheat and also used $\mathrm{CaSiO}_{3}$, found a rate-dependent reduction in the yield of wheat, a result attributed to the negative effect of the high $\mathrm{pH}$ induced by the high application rates of $\mathrm{CaSiO}_{3}$ on the solubility of several essential plant nutrients. Johnson et al. (2014) also reported that the application of $\mathrm{CaSiO}_{3}$ induced an increase in soil $\mathrm{pH}$; the release of large amounts of calcium ions prevent the bioavailability and absorption of silicon and other minerals by plants. Given that the source of Si used by these authors and in our studies are similar, it is plausible that the $\mathrm{pH}$-induced effect of $\mathrm{CaSiO}_{3}$ may have played a role in the reduction of number of tillers obtained under inoculated and non-inoculated conditions in the present study. Most of the previous studies on the beneficial effects of Si on plant growth, resistance and ability to withstand biotic and abiotic stresses were conducted using hydroponics, with periodic (daily or weekly) correction of the $\mathrm{pH}$ of the solution (Dufey et al., 2009, 2012; Mbonankira, 2014; Zellner et al., 2011). The present study, carried out in pots, offered no opportunity for periodic $\mathrm{pH}$ correction of the growing medium. A repeat of the present study using hydroponics with periodic $\mathrm{pH}$ adjustment, other sources of $\mathrm{Si}$ and foliar application to increase the efficiency of absorption will offer more insight on the integrated management of RYMV with host plant resistant and Si.

\section{Conflicts of Interest}

No potential conflict of interest relevant to this article was reported.

\section{Acknowledgments}

This paper was part of the Ph.D. research of the first author with financial support from the Pan African University Institute of Life and Earth Sciences (Including Health and Agriculture), of the African Union hosted by the University of Ibadan, Ibadan, Nigeria. We are grateful to AfricaRice Gene bank for providing the plant materials and the Plant Pathology team of Africa Rice Benin for their technical support and for providing the virus strain used in this study.

\section{References}

Abed-Ashtiani, F., Kadir, J.-B., Selamat, A.-B., Hanif, A. H. B.-M. and Nasehi, A. 2012. Effect of foliar and root application of silicon against rice blast fungus in MR219 rice variety. Plant Pathol. J. 28:164-171.

Abo, M. E., Sy, A. A. and Alegbejo, M. D. 1997. Rice yellow mottle virus (RYMV) in Africa: evolution, distribution, economic significance on sustainable rice production and management strategies. J. Sustain. Agric. 11:85-111.

Agahi, K., Fotokian, M. H. and Farshadfar, E. 2007. Correlation and path coefficient analysis for some yield-related traits in rice genotypes (Oryza sativa L.). Asian J. Plant Sci. 6:513517.

Agnoun, Y. 2013. Contribution to the valorization of the African rice Oryza glaberrima landraces: agronomic and genetic importance. Ph.D. thesis. University of Abomey-Calavi, Godomey, Benin.

Akinwale, M. G., Gregorio, G., Nwilene, F., Akinyele, B. O., Ogunbayo, S. A. and Odiyi, A. C. 2011. Heritability and correlation coefficient analysis for yield and its components in rice (Oryza sativa L.). Afr. J. Plant Sci. 5:207-212.

Albar, L., Bangratz-Reyser, M., Hébrard, E., Ndjiondjop, M.N., Jones, M. and Ghesquière, A. 2006. Mutations in the eIF(iso)4G translation initiation factor confer high resistance of rice to rice yellow mottle virus. Plant J. 47:417-426. 
Bakker, W. 1970. Rice yellow mottle, a mechanically transmissible virus disease of rice in Kenya. Neth. J. Plant Pathol. 76:53-63.

Bengsch, E., Korte, F., Polster, J., Schwenk, M. and Zinkernagel, V. 1989. Reduction in symptom expression of belladonna mottle virus infection on tobacco plants by boron supply and the antagonistic action of silicon. Z. Naturforsch. 44:777-780.

Datnoff, L. E., Rodrigues, F. A. and Seebold, K. W. 2007. Silicon and plant disease. In: Mineral nutrition and plant disease, eds. by L. E. Datnoff, W. H. Elmer and D. M. Huber, pp. 233246. APS Press, St. Paul, MN, USA.

Diagne, A., Alia, D. Y., Amovin-Assagba, E., Wopereis, M. C. S., Saito, K. and Nakelse, T. 2013. Farmer perceptions of the biophysical constraints to rice production in sub-Saharan Africa, and potential impact of research. In: Realizing Africa's rice promise, eds. by M. C. S. Wopereis, D. E. Johnson, N. Ahmadi, E. Tollens and A. Jalloh, pp. 46-68. CABI, Wallingford, UK.

Dufey, I., Gheysens, S., Ingabire, A., Lutts, S. and Bertin, P. 2014. Silicon application in cultivated rices (Oryza sativa $\mathrm{L}$ and Oryza glaberrima Steud) alleviates iron toxicity symptoms through the reduction in iron concentration in the leaf tissue. $J$. Agron. Crop Sci. 200:132-142.

Dufey, I., Hakizimana, P., Draye, X., Lutts, S. and Bertin, P. 2009. QTL mapping for biomass and physiological parameters linked to resistance mechanisms to ferrous iron toxicity in rice. Euphytica 167:143-160.

Dufey, I., Hiel, M.-P., Hakizimana, P., Draye, X., Lutts, S., Koné, B., Dramé, K. N., Konate, K. A. Sie, M. and Bertin, P. 2012. Multi-environment quantitative trait loci mapping and consistency across environments of resistance mechanisms to ferrous iron toxicity in rice. Crop Sci. 52:539-550.

Elsharkawy, M. M. and Mousa, K. M. 2015. Induction of systemic resistance against papaya ring spot virus (PRSV) and its vector Myzus persicae by Penicillium simplicissimum GP172 and silica $\left(\mathrm{SiO}_{2}\right)$ nanopowder. Int. J. Pest Manag. 61:353358.

Epstein, E. 1994. The anomaly of silicon in plant biology. Proc. Natl. Acad. Sci. U. S. A. 91:11-17.

Epstein, E. 1999. Silicon. Annu. Rev. Plant Physiol. Plant Mol. Biol. 50:641-664.

Fargette, D., Pinel, A., Traoré, O., Ghesquière, A. and Konaté, G. 2002. Emergence of resistance-breaking isolates of rice yellow mottle virus during serial inoculations. Eur. J. Plant Pathol. 108:585-591.

Fiamohe, R., Demont, M., Saito, K., Roy-Macauley, H. and Tollens, E. 2018. How can west African rice compete in urban markets? A demand perspective for policymakers. EuroChoices 17:51-57.

Food and Agriculture Organization of the United Nations. 2017a. Statistical data base. Rome, Italia. Version: December 2017. URL http//:www.fao.org/economic/RMM/ [6 January 2018].

Food and Agriculture Organization of the United Nations. 2017b. Statistical data base. Rome, Italia. Version: December 2017.
URL http://www.fao.org/faostat/en/\#data/ [25 December 2017].

Food and Agriculture Organization of the United Nations. 2019. Crop prospects and food situation - quarterly global report no. 3. Version: September 2019. Rome. URL http://www.fao.org/ giews/ [6 October 2019].

Frantz, J. M., Khandekar, S. and Leisner, S. 2011. Silicon differentially influences copper toxicity response in silicon-accumulator and non-accumulator species. J. Am. Soc. Hortic. Sci. 136:329-338.

Hébrard, E., Pinel-Galzi, A., Oludare, A., Poulicard, N., Aribi, J., Fabre, S., Issaka, S., Mariac, C., Dereeper, A., Albar, L., Silué, D. and Fargette, D. 2018. Identification of a hypervirulent pathotype of rice yellow mottle virus: a threat to genetic resistance deployment in West-Central Africa. Phytopathology 108:299-307.

Heuer, S., Miézan, K. M., Sié, M. and Gaye, S. 2003. Increasing biodiversity of irrigated rice in Africa by interspecific crossing of Oryza glaberrima (Steud.) $\times$ O. sativa indica (L.). Euphytica 132:31-40.

Huang, R., Jiang, L., Zheng, J., Wang, T., Wang, H., Huang, Y. and Hong, Z. 2013. Genetic bases of rice grain shape: so many genes, so little known. Trends Plant Sci. 18:218-226.

Hull, R. 1988. The sobemovirus group. In: The plant viruses, ed. by R. Koenig, pp. 113-146. Springer, Boston, MA, USA.

International Rice Research Institute. 2002. Standard evaluation system for rice. 5th ed. International Rice Research Institute, Manila, Philippine. 21 pp.

Issaka, S., Basso, A., Sorho, F., Onasanya, A., Haougui, A., Sido, A. Y., Aké, S., Fargette, D. and Séré, Y. 2012. Diagnosis and importance of rice yellow mottle disease epidemics in Niger Republic. J. Appl. Biosci. 50:3501-3511.

Janislampi, K. W. 2012. Effect of silicon on plant growth and drought stress tolerance. Utah State University. Version: 2012. URL http://digitalcommons.usu.edu/etd/1360/ [10 January 2018].

Johnson, C. E., Driscoll, C. T., Blum, J. D., Fahey, T. J. and Battles, J. J. 2014. Soil chemical dynamics after calcium silicate addition to a northern hardwood forest. Soil Sci. Soc. Am. J. 78:1458-1468.

Jones, M. P., Dingkuhn, M., Aluko, G. K. and Semon, M. 1997. Interspecific Oryza sativa L. $\times$ O. glaberrima Steud. progenies in upland rice improvement. Euphytica 94:237-246.

Kam, H., Laing, M. D., Ouoba, J. and Ndjiondjop, M.-N. 2013. Rice traits preferred by farmers and their perceptions of rice yellow mottle virus (RYMV) disease in cascades region of Burkina Faso. Afr. J. Agric. Res. 8:2703-2712.

Kobayashi, K., Sekine, K.-T. and Nishiguchi, M. 2014. Breakdown of plant virus resistance: can we predict and extend the durability of virus resistance? J. Gen. Plant Pathol. 80:327336.

Kouassi, N. K., N'Guessan, P., Albar, L., Fauquet, C. M. and Brugidou, C. 2005. Distribution and characterization of rice yellow mottle virus: a threat to African farmers. Plant Dis. 
89:124-133.

Koudamiloro, A., Nwilene, F. E., Togola, A. and Akogbeto, M. 2015. Insect vectors of rice yellow mottle virus. J. Insects 2015:721751.

Kumar, A., Kumar, H., Gupta, V., Khosla, G. and Sharma, P. K. 2011. Correlation and path coefficient analysis for yield and yield component traits in rice (Oryza sativa L.). Agric. Sci. Digest 31:275-279.

Kumar, C. and Nilanjaya. 2014. Correlation and path coefficient analysis of yield components in aerobic rice (Oryza sativa L.). Bioscan 9:907-913.

Laha, G. S., Singh, R., Ladhalakshmi, D., Sunder, S., Prasad, M. S., Dagar, C. S. and Babu, V. R. 2017. Importance and management of rice diseases: a global perspective. In: Rice production worldwide, eds. by B. S. Chauhan, K. Jabran and G. Mahajan, pp. 303-360. Springer, Cham, Switzerland.

Li, R., Li, M., Ashraf, U., Liu, S. and Zhang, J. 2019. Exploring the relationships between yield and yield-related traits for rice varieties released in China from 1978 to 2017. Front. Plant Sci. 10:543.

Liang, Y. 1999. Effects of silicon on enzyme activity and sodium, potassium and calcium concentration in barley under salt stress. Plant Soil 209:217-224.

Liang, Y., Sun, W., Zhu, Y.-G. and Christie, P. 2007. Mechanisms of silicon-mediated alleviation of abiotic stresses in higher plants: a review. Environ. Pollut. 147:422-428.

Liang, Y., Wong, J. W. C. and Wei, L. 2005. Silicon-mediated enhancement of cadmium tolerance in maize (Zea mays L.) grown in cadmium contaminated soil. Chemosphere 58:475483.

Ma, J. F., Miyake, Y. and Takahashi, E. 2001. Silicon as a beneficial element for crop plants. Stud. Plant Sci. 8:17-39.

Marschner, H. 1995. Mineral nutrition of higher plants. 2nd ed. Academic Press, London, UK. 889 pp.

Mbonankira, J. E. 2014. Silicon alleviation of ferrous iron toxicity in rice: a physiological and genetic approach. $\mathrm{Ph}$.D. thesis. Université Catholique de Louvain, Ottignies-Louvain-laNeuve, Belgium.

Meharg, C. and Meharg, A. A. 2015. Silicon, the silver bullet for mitigating biotic and abiotic stress, and improving grain quality, in rice? Environ. Exp. Bot. 120:8-17.

Meyer, J. H. and Keeping, M. G. 2001. Past, present and future research of the role of silicon for sugarcane in southern Africa. In: Silicon in agriculture, Vol. 8, eds. by L. E. Datnoff, G. H. Snyder and G. H. Korndörfer, pp. 257-275. Elsevier, Amsterdam, The Netherlands.

Moldenhauer, K., Counce, P. and Hardke, J. 2004. Rice growth and development. In: Rice production handbook, ed. by J. T. Hardke, pp. 9-20. University of Arkansas, Little Rock, AK, USA.

Narayanaswamy, C., Tubana, B. and Chanda, S. 2012. Biomass and silicon uptake of wheat in response to different levels of plant-available silicon. In: $A S A, C S S A$ and $S S S A$ International Annual Meeting. American Society of Agronomy, Madison,
WI, USA.

Ndjiondjop, M. N., Semagn, K., Sie, M., Cissoko, M., Fatondji, B. and Jones, M. 2008. Molecular profiling of interspecific lowland rice populations derived from IR64 (Oryza sativa) and Tog5681 (Oryza glaberrima). Afr. J. Biotechnol. 7:42194229.

Oladosu, Y., Rafii, M. Y., Magaji, U., Abdullah, N., Miah, G., Chukwu, S. C., Hussin, G., Ramli, A. and Kareem, I. 2018. Genotypic and phenotypic relationship among yield components in rice under tropical conditions. Biomed. Res. Int. 2018:8936767.

Oludare, A., Tossou, H. T., Kini, K. and Silué, D. 2016. Diversity of rice yellow mottle virus in Benin and Togo and screening for resistant accessions. J. Phytopathol. 164:924-935.

Orjuela, J., Thiémélé Deless, E. F., Kolade, O., Chéron, S., Ghesquière, A. and Albar, L. 2013. A recessive resistance to rice yellow mottle virus is associated with a rice homolog of the CPR5 gene, a regulator of active defense mechanisms. Mol. Plant-Microbe Interact. 26:1455-1463.

Pidon, H., Chéron, S., Ghesquière, A. and Albar, L. 2020. Allele mining unlocks the identification of RYMV resistance genes and alleles in African cultivated rice. BMC Plant Biol. 20:222.

Pidon, H., Ghesquière, A., Chéron, S., Issaka, S., Hébrard, E., Sabot, F., Kolade, O., Silué, D. and Albar, L. 2017. Fine mapping of RYMV3: a new resistance gene to rice yellow mottle virus from Oryza glaberrima. Theor. Appl. Genet. 130:807818.

Pinel-Galzi, A., Hébrard, E., Traoré, O., Silué, D. and Albar, L. 2018. Protocol for RYMV inoculation and resistance evaluation in rice seedlings. Bio-protocol 8:e2863.

Pinel-Galzi, A., Traoré, O., Séré, Y., Hébrard, E. and Fargette, D. 2015. The biogeography of viral emergence: rice yellow mottle virus as a case study. Curr. Opin. Virol. 10:7-13.

Sakamoto, T. and Matsuoka, M. 2008. Identifying and exploiting grain yield genes in rice. Curr. Opin. Plant Biol. 11:209-214.

Sakr, N. 2016. Silicon control of bacterial and viral diseases in plants. J. Plant Prot. Res. 56:331-336.

Savant, N. K., Snyder, G. H. and Datnoff, L. E. 1996. Silicon management and sustainable rice production. Adv. Agron. 58:151-199.

Séré, Y., Fargette, D., Abo, M. E., Wydra, K., Bimerew, M., Onasanya, A. and Akator, S. K. 2013. Managing the major diseases of rice in Africa. In: Realizing Africa's rice promise, eds. by M. C. S. Wopereis, D. E. Johnson, N. Ahmadi, E. Tollens and A. Jalloh, pp. 213-228. CABI, Wallingford, UK

Sharifi, P. 2018. Sequential path analysis for determination of relationships between yield-related characters and yield and amylose content in rice. Philipp. J. Crop Sci. 43:73-79.

Sié, M., Dogbe, S. Y. and Coulibaly, M. 2005. Selection of interspecific hybrids $(O$. sativa $\times O$. glaberrima or lowland NERICAs) and intraspecifics adapted to rainfed lowland growing conditions. Int. Rice Comm. Newsl. 54:47-51.

Tamai, K. and Ma, J. F. 2003. Characterization of silicon uptake 
by rice roots. New Phytol. 158:431-436.

Thiémélé, D., Boisnard, A., Ndjiondjop, M.-N., Chéron, S., Séré, Y., Aké, S., Ghesquière, A. and Albar, L. 2010. Identification of a second major resistance gene to rice yellow mottle virus, RYMV2, in the African cultivated rice species, O. glaberrima. Theor. Appl. Genet. 121:169-179.

Traoré, O., Pinel-Galzi, A., Sorho, F., Sarra, S., Rakotomalala, M., Sangu, E., Kaneyeka, Z., Séré, Y., Konaté, G. and Fargette, D. 2009. A reassessment of the epidemiology of rice yellow mottle virus following recent advances in field and molecular studies. Virus Res. 141:258-267.

Tsujimoto, Y., Muranaka, S., Saito, K. and Asai, H. 2014. Limited Si-nutrient status of rice plants in relation to plant-available $\mathrm{Si}$ of soils, nitrogen fertilizer application, and rice-growing environments across Sub-Saharan Africa. Field Crops Res. 155:19.

Wopereis, M. 2013. New generation rice varieties unveiled for Africa. Version: November 2013. URL http:/www.africarice. org/warda/newsrel-ARICA-May-13.asp/ [13 October 2017].

Zellner, W., Frantz, J. and Leisner, S. 2011. Silicon delays tobacco ringspot virus systemic symptoms in Nicotiana tabacum. $J$. Plant Physiol. 168:1866-1869.

Zhu, Z., Wei, G., Li, J., Qian, Q. and Yu, J. 2004. Silicon alleviates salt stress and increases antioxidant enzymes activity in leaves of salt-stressed cucumber (Cucumis sativus L.). Plant Sci. 167:527-533. 